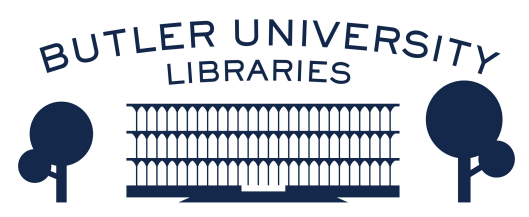

Journal of Hindu-Christian Studies

January 2004

\title{
Book Review: "Singing the Body of God. The Hymns of Vedantadesika in their South Indian Tradition"
}

Anand Amaladass

Follow this and additional works at: https://digitalcommons.butler.edu/jhcs

Part of the Religion Commons

\section{Recommended Citation}

Amaladass, Anand (2004) "Book Review: "Singing the Body of God. The Hymns of Vedantadesika in their South Indian Tradition"," Journal of Hindu-Christian Studies: Vol. 17, Article 20.

Available at: https://doi.org/10.7825/2164-6279.1329

The Journal of Hindu-Christian Studies is a publication of the Society for Hindu-Christian Studies. The digital version is made available by Digital Commons @ Butler University. For questions about the Journal or the Society, please contact cbauman@butler.edu. For more information about Digital Commons @ Butler University, please contact digitalscholarship@butler.edu. 
more Western view on the limits of human nature. (92) What he argues for is a critical openness to both points of view, an attitude he sees to be a necessity for good comparative scholarship.

The present book has focused on the place of language and psychology in the debate about human nature. In his final remarks Coward notes that such a discussion has profound implications also for philosophy and theology. It is to be the subject of his next book. The readers of
Yoga and Psychology await the appearance of its sequel with great anticipation. Harold Coward has done a marvelous service in summarizing and critiquing very disparate voices on a most significant and difficult theme.

Bradley Malkovsky

University of Notre Dame

\section{Singing the Body of God. The Hymns of Vedantadesika in their South Indian Tradition. Steven Paul Hopkins. New Delhi: Oxford University Press, 2002, $x x+344$ pp.}

VEDANTA Desika, a fourteenth century poet-philosopher from South India, is not known very much outside his traditional circles, mainly because there are not many translations of his works in any of the European languages. He wrote in Sanskrit, Tamil and manipravala, a form of TamilSanskrit mixture. Hence this publication does a great service to a thinker like Desika by drawing the attention of the wider academic world.

This work concentrates on the devotional hymns of Desika. It is divided into three parts containing seven chapters besides the introduction and conclusion. After dealing with the details of the author's background based on internal evidence, traditional accounts and several legends about the author, the hymns are taken for analysis and discussion. Chapters 3 and 4 deal with three of the most important Tamil works of Desika. Chapters 6 and 7 deal with hymns in Sanskrit and Prakrit, and they are all Desika's stotras in praise of the forms of Vishnu. The concluding chapter sums up the major themes discussed here like Desika as poet-philosopher, the relationship between Tamil, Sanskrit and Prakrit, the roles of intellect and emotion in Desika's bhakti poetics, the icons, the body of God and Desika's theology of beauty.

The title of the book significantly highlights the content of these hymns. The author argues that, "these poems, in literally bodying forth the god, become themselves, in a particularly vivid way, "verbal icons' of icons." (p.139). In fact these poems describe Lord Vishnu from head to foot. This type of description, limb by limb, comes from the poetics of early Indian Kavya, both Hindu and Buddhist. One can here cite examples of the Alvars in praise of Lord Visnu and Abhirami Bhattar in praise of the goddess Abhirami.

Desika writes a commentary on Tiruppanalvars' Amalanatipiran, one of the most important descriptions of the beloved god in the Vaishnava Tamil Tradition beginning with the Lotus feet, the red cloth He wears on His waist, shining navel, waistband around his lovely belly, the chest, his throat, his red lips, face, and the dark body. It is said Vishnu's beautiful body seizes the heart of this Tamil devotional poet like a beloved seizes the heart of his lover, inspiring in him a rich "language of joy."(p.147) One should keep in mind that here one deals with cultic context of temple 
and ritual. Desika's poem Bhagavaddhyana sopanam ("The Ladder Meditation on the Lord") is translated here to illustrate Desika's experience of Ranganathan.

These poems also allude to yogic visualization practices based on the southern tantra, Pancaratra Agamas. In tantric meditation the adepts are taught, by way of searching seed mantras, how to construct within their own bodies the body of the deity. So too these poems express the experience of the poet in assimilating the image of the Lord in his own heart. Singing. these hymns or reciting them bodies forth god. "They articulate both the spontaneous enjoyment of the beauty of god and the rarified ritual map of a spiritual elite, the connative and cognitive. It is within this meditational tradition that we are able perhaps to understand these poems themselves as "icons", "bodies" of God." (p.165). Thus they are 'icons of icons'.

The bhakti tradition is not just emotional outpouring of the devotees without the intellectual component, and one tends at times to juxtapose these devotional hymns with the treatises that are speculative or rational. This might perhaps devalue the hymns. But then a serious analysis and study of these hymns, as this volume illustrates, point out the richness of these sources for our better understanding of a given religious tradition and the author's theological perspectives. Secondly, the poet-saints give importance to the body, the material aspect as is evident from their metaphors and the type of language they use. The sense of touch, smell, or taste is indicative of closeness, intimacy etc, and it is different from the sense of hearing (sruti) and seeing (drshti) where the 'distance' is presupposed. It has a theological significance in the context of Indian religious tradition, where body is supposedly underestimated.

This volume is commendable for its scholarly presentation. It brings to light a religious thinker of the fourteenth century, takes note of the previous publications dealing with Tamil works, locating the author Desika within the development of Srivaishnava tradition and the theology of the Alvars, the poet saints. Usually Desika's language is considered difficult for ordinary readers and left to the erudite pandits, but this publication makes the rich heritage of the author accessible to all.

Anand Amaladass Chennai

\section{The Asian Synod: Texts and Commentaries. Peter C. Phan, ed. Maryknoll, N.Y.: Orbis Books, 2002, xiii + 352 pp.}

AT the dawn of the new millennium, Pope John Paul II called the Catholic Church to begin a renewed evangelization. To discuss this goal, a series of five synods of bishops from five main regions of the earth were held in Rome. Peter Phan, a well known Catholic theologian from Vietnam and many years a professor in the U.S., selected and edited documents from the 1998 Synod of Asian Bishops. The book includes both formal documents which preceded the event and documents from the Synod itself. It also includes Ecclesia in Asia, a comprehensive document which John Paul II developed after the Synod. Short analyses of the documents and proceedings composed by theologians selected by Phan are interspersed throughout the book.

The bishops in attendance spanned the geographical swath from Lebanon to Japan. A wide variety of perspectives and positions were thus represented. In spite of this, there was a clear consensus among the bishops that Jesus is generally perceived by Asians 